\title{
THE SEARCHING FOR SELF-IDENTITY IN KAZUO ISHIGURO'S NEVER LET ME GO
}

\author{
Rahmi Munfangati ${ }^{1,{ }^{*}}$, Aisyah Nur Handayani ${ }^{2}$ \\ ${ }^{1}$ English Education Department, Faculty of Teacher Training and Education, Universitas Ahmad Dahlan, \\ Jl. Ahmad Yani (Ringroad Selatan) Tamanan Banguntapan Bantul, Yogyakarta 55166, Indonesia \\ ${ }^{2}$ English Education Department, Faculty of Teacher Training and Education, Universitas Ahmad Dahlan, \\ Jl. Ahmad Yani (Ringroad Selatan) Tamanan Banguntapan Bantul, Yogyakarta 55166, Indonesia
}

\section{ARTICLE INFO}

Keywords:

Self-identity

Kazuo Ishiguro

Never Let Me Go

Psychological approach

Article History:

Received: 02/04/2020

Accepted: $25 / 11 / 2021$

Available Online:

30/11/2021

\begin{abstract}
A B S T RACT
Self-identity is an aspect that every human in the world has. Without it, a person is in danger of being negatively affected by those around him/her and by the outside world. Some people are grappling with this identity-forming phase in their search for self-definition. This is reflected in Never Let Me Go by Kazuo Ishiguro. Therefore, this research aims to describe the main characters' search for self-identity as seen in the novel. The type of this research was library research. This research applied a psychological approach, and the data were analyzed using the descriptive qualitative method. The results showed that Kathy and Tommy's quest to find their true selves occurred in childhood, adolescence, and adulthood stages. Narrated by Kathy, she flashed back the memories of how they, Kathy and Tommy, are puzzled because of too many mysteries in Hailsham, the boarding school where they live. They connected each puzzle which could be the answer. But, in the novel, the question they belong to for being different brought them to another question. The process of findings itself flowed as long as they grew. In the end, they found information about their identity as a clone and as an individual.
\end{abstract}

2442-305X / C 2021 The Authors, this is open access article under the (CC-BY-NC) license (https://creativecommons.org/licenses/by-nc/4.0/), DOI:10.19105/ojbs.v15i2.3205

\footnotetext{
$\overline{\text { * Corresponding Author: }}$

Email address: rahmi@pbi.uad.ac.id (R. Munfangati)
}

\section{A. Introduction}

Identities are the social group's attributes and characteristics, social relationships, responsibilities, and memberships, which determine what one's identity is. Some researchers defined self-identity. Self often refers to "about me."1 The word self involves both the thinking actor ("I am thinking") and the thinking entity ("about me"). The actor can

${ }^{1}$ Daphna Oyserman, Kristen Elmore, and George Smith, "Self, Self-Concept, and Identity," in Handbook of Self and Identity, ed. Mark R. Leary and June Price (New York: Guilford Press, 2012), 69-104. 
both think and is sure of doing that. While identity, as stated by Tajfel and Turner, ${ }^{2}$ is conceived as a means to make sense of some dimension or part of the concept of oneself. The definition of oneself is a thought or set of thoughts regarding what our identity is. In other words, what a person remembers, how they remember it, and how they make sense of the memory are profoundly influenced by selfconceptions. $^{3}$ So, self, self-concept, and identity can be considered settled components, with parts of selfconceptions forming "me" and identities becoming a piece of self-aspect. ${ }^{4}$

Identity and self-concept offer responses to the fundamental problems "Who am I?" Where do I belong? And how can I (or come in) fit in?"5 In society, every self-idea is expected to be unique, distinct from any other self, and privatecompletely understandable just to oneself. If we think about ourselves, including personal and group identities, what comes to mind is self-conception and identity.

The self has been associated with various life circumstances and results and is viewed as a mental instrument self-idea fluctuates in its substance and viability. ${ }^{6}$ A person's identity is a subject of interest in humanities, cognitive science, psychology, and psychoanalysis within a

\footnotetext{
${ }^{2}$ Oyserman, Elmore, and Smith. 7.

${ }^{3}$ Daphna Oyserman, "Self-Concept and Identity," in Intraindividual Processes, ed. Abraham Tesser and Norbert Schwarz (Malden, MA: Blackwell Publishers, 2001), 499-517.

4 Oyserman, Elmore, and Smith, "Self, SelfConcept, and Identity.", 8.

${ }^{5}$ Oyserman, "Self-Concept and Identity," 499.

${ }^{6}$ Oyserman, "Self-Concept and Identity," 499.
}

culture. Identity itself exists in the past, present, and future time frames. ${ }^{7}$ Identities might be based on the past-what used to be real of one, the present-what is real of one now, or the future-the individual you hope or want to turn into the individual you feel compelled to try to become or the individual you are afraid of becoming. ${ }^{8}$ Identities are focused; they give a focal point of importance and concentrate on considering particular aspects of the immediate situation, but not others.

Self-identity, in short, is a thing every person has in the world. Without it, a person is in danger of being influenced negatively by those around him and the outside world. Some people in their quest for self-definition are struggling with this identity-forming process. This is reflected in Never Let Me Go novel written by Kazuo Ishiguro.

Kazuo Ishiguro is a Japanese-born contemporary British author who was awarded the 2017 Nobel Prize in Literature. ${ }^{9}$ Never Let Me Go is the sixth novel by Kazuo Ishiguro. It tells a story about a journey of searching for selfidentity.

The story's setting was in England in the late 1990s; the novel narrates Kathy $\mathrm{H}$, a carer, donor, and student in Hailsham. In a boarding school where she grows, studies, and meets, she has Ruth

\footnotetext{
7 Mardi. J. Horowitz, "Self-Identity Theory and Research Methods," Journal of Research Practice 8, no. 2 (2012): 1-11.

8 Oyserman, Elmore, and Smith, "Self, SelfConcept, and Identity." 2.

9"The Nobel Prize in Literature 2017," 2017, https://www.nobelprize.org/prizes/literature/2017/su mmary/.
} 
and Tommy's best friends. In Hailsham, they live without knowing anything either about donation. But, Kathy knows, there is something mysterious in Hailsham. The guardians, the teachers who take care of them since they are babies, treat them strictly and intensively. They should have a check-up once a week and be forbidden to cross the border Hailsham's areas. They also should create art no matter what it is, and the guardians will collect it three or four times a year. Kathy $\mathrm{H}$ puzzles about it all. They share every idea, information, and secret of what they find in Hailsham with Ruth and Tommy.

Later in the novel, they know from Miss Lucy, one of the guardians, who tells them the truth about why they are in Hailsham and what their real identity is. Starting right there, they, one by one, are able to reveal other truths. Until they are being adults and quit from Hailsham, they meet another chance to know their identity. In Cottage, the place they socialize and learn in adulthood, they begin their true life and journey to find their identity.

Never Let Me Go had awarded and filmed. It was shortlisted for the 2005 Booker Prize, the Arthur C. Clarke Award in 2006, and the 2005 National Book Critics Circle Award. ${ }^{10}$ TIME magazine called it the best novel of 2005, and from 1923 to 2005; it included the novel in the

10 Sean Matthews and Sebastian Groes, Kazuo Ishiguro: Contemporary Critical Perspectives. (London: Continuum International Pub. Group, 2010). 16.
TIME 100 Best English Novels. ${ }^{11}$ This was also given an ALA Alex Award in 2006. ${ }^{12}$ It was adapted into a film in 2010 , directed by Mark Romanic. It was launched in September 2011 in Indonesia. ${ }^{13}$

Previous work exploring the search for self-identity in Never Let Me Go novel has not been found so far. Still, several similar studies examining formal and material objects are sufficiently inspiring in this research.

One article that analyzed Never Let Me Go is The Othering in Kazuo Ishiguro's Never Let Me Go by Matava Vichiensing. This article explores the notion of 'othering' in the novel as part of a post-colonial theory. ${ }^{14}$ The results indicate that the research of Never Let Me Go by Kazuo Ishiguro helps explain and consider how the harmful effects of the othering cycle impact unnecessary actions in society as a whole.

The second inspirational paper was written by Yeung V. entitled Mortality and Memory in Kazuo Ishiguro's Never Let Me Go. This article proposes a reading of Never Let Me Go by Kazuo Ishiguro to

\footnotetext{
11 Laura Miller, Literary Wonderlands: A Journey through the Greatest Fictional Worlds Ever Created (London: Modern Books, 2017).

12 American Library Association, "2006 Alex Awards," 2007, http://www.ala.org/yalsa/booklistsawards/bookawar ds/alexawards/alex06.

${ }^{13}$ Taufik Wahyu Skripka, "Kathy H's Struggle For Getting True Love In Kazuo Ishiguro's Never Let Me Go Novel (2005): An Individual Psychological Approach" (Universitas Muhammadiyah Surakarta, 2014).

14 Matava Vichiensing, "The Othering in Kazuo Ishiguro's Never Let Me Go," Advances in Language and Literary Studies 8, no. 4 (2017): 126-35 https://doi.org/10.7575/aiac.alls.v.8n.4p.126.
} 
reflect human mortality. ${ }^{15}$ The tragic love tale, set in an alternate England in the 1990s, revolves around the relationship between three human clones. The novel portrays the growing consciousness of the trio about their destiny and how they cope with the burden and anxiety arising from knowing what lies before them. The article explores how the situation represents a conflict between human beings and mortality. The topic focuses on the relationship between death and memory, which is presented as a mental mechanism that can assist in the story's assuage of the mental death trauma.

Another paper that discusses Never Let Me Go is entitled Exploring an AntiUtopian Subtext in Kazuo Ishiguro's Never Let Me Go by Arnab Chatterjee. This paper "revisits" this pastoral concept in the novel in two ways: first, it explores the use of this comparatively lesser- genre today; second, by revisiting it, it re- and reveals how the author uses it to his purposes to portray the development cycle as essentially anti-pastoral, antiutopian, and hence dystopic. ${ }^{16}$

Thus, this study is undoubtedly distinct from previous studies. The researchers would discuss the search for self-identity in Never Let Me Go novel, using a psychological approach.

\footnotetext{
${ }^{15}$ Virginia Yeung, "Mortality and Memory in Kazuo Ishiguro's Never Let Me Go," Transnational Literature 9, no. 2 (2017): 1-13, https://doaj.org/article/d583068eff424a06853bde27 $8 f 5 c 4 b c c$.

16 Arnab Chatterjee, "Exploring an Anti-Utopian Subtext in Kazuo Ishiguro's Never Let Me Go," Interdisciplinary Literary Studies 21, no. 2 (2019): 109-24,

https://doi.org/10.5325/intelitestud.21.2.0109.
}

\section{The Concept of Searching for Self- Identity}

In finding how the self, self-concept, and identity come from, there are three core notions about it. The three notions are self and identities are conceptions of minds, self and identity are social products, and self and identity are forces for actions. ${ }^{17}$

The first, self and identity, are concepts of the mind. Theories of self and identity argued that mental objects are self and identity that is something memorable embodied. This potential is set to rise early. Most children 18 months of age and almost all children 24 months of age brush their foreheads to remove an unobtrusive smudge produced by painting their foreheads. ${ }^{18}$ This response is interpreted as meaning that children know what they look like and know there should not be a smudge on their foreheads. This imagebased self-recognition is not restricted to the surface; children often find a sticker subtly put on their legs at this age. ${ }^{19}$

The second, self and identity, are social products. In general terms, self and identity are, in at least three ways, social products. First, human beings do not construct themselves out of the discussion; maybe, what is conceivable,

\footnotetext{
17 Oyserman, Elmore, and Smith, "Self, SelfConcept, and Identity.", 8-9.

${ }^{18}$ Michael and Jeanne Brooks-Gunn Lewis, Social Cognition and the Acquisition of Self (New York: Plenum, 1979), https://doi.org/10.1007/978-1-46843566-5.

${ }^{19}$ Mark Nielsen, Thomas Suddendorf, and Virginia Slaughter, "Mirror Self-Recognition beyond the Face," Child Development 77, no. 1 (2006): 17685 , https://doi.org/10.1111/j.14678624.2006.00863.x.
} 
significant, and needs to be clarified comes from the social context-from what is vital for others. This capacity that human beings are likely to portray themselves as to what is essential in their time and put: group enrollments (e.g., faith, race, or gender), family parts, appearance, college accomplishment, or athletic ability will be more or less vital fundamentally based on what is esteemed in one's way of life and one's zone inside the social hierarchy. Second, being a self needs others to assist and improve one's self-confidence, to platform the feeling that one's self matters and that one's moves will create results. This implies that in settings that give such scaffoldings, individuals ought to be better able to achieve their goals and then in circumstances that do not. Third, the currently essential elements of one's self and identity are decided by what is now relevant.

The last is self and identity are forces for action. One common topic among the theorists of self and identity is that actions matters to the self. Yet, it has been hard to understand how one feels about oneself influences behavior rather than just being concerned about it. Selfinfluences behavior manages whether or not and how people think about themselves and show that this impacts their subsequent behavior. Participants are asked to sit in front of a mirror to allow the self-realizing ${ }^{20}$ or to do something else

${ }^{20}$ Charles S. Carver and Michael F. Scheier, "SelfFocusing Effects of Dispositional SelfConsciousness, Mirror Presence, and Audience Presence," Journal of Personality and Social to bring the self to mind, like as signing their name ${ }^{21}$, telling what makes them equal or distinct from others ${ }^{22}$ or circling first-person singular pronouns. ${ }^{23}$ Each of these paradigms impacts responses, but the precise nature of the effects of making the conduct self-significant depends on the interaction between the self-facets in the context and the task at hand. ${ }^{24}$

To look carefully at these processes, frequently controlling the salience of one specific self-viewpoint is essential. Participants in one study, for example, provided programmed feedback to convince them to think they were generally skilled or unskilled. It influenced their self-esteem and subsequent adverse reactions to others. ${ }^{25}$

Psychology 36, no. 3 (1978): 324-32, https://doi.org/10.1037/0022-3514.36.3.324.

${ }^{21}$ Keri L. Kettle and Gerald Häubl, "The Signature Effect: Signing Influences Consumption-Related Behavior by Priming Self-Identity," Journal of Consumer Research 38, no. 3 (2011): 474-89, https://doi.org/10.1086/659753.

22 David Trafimow, Harry C. Triandis, and Sharon G. Goto, "Some Tests of the Distinction Between the Private Self and the Collective Self," Journal of Personality and Social Psychology 60, no. 5 (1991): 649-55, https://doi.org/10.1037/00223514.60.5.649

${ }^{23}$ Wendi L. Gardner, Shira Gabriel, and Angela Y. Lee, 'I' Value Freedom, but 'We' Value Relationships: Self-Construal Priming Mirrors Cultural Differences in Judgment," Psychological Science 10, no. 4 (1999): 321-26, https://doi.org/10.1111/1467-9280.00162; Jie Sui and Shihui Han, "Self-Construal Priming Modulates Neural Substrates of Self-Awareness," Psychological Science 18, no. 10 (2007): 861-66, https://doi.org/10.1111/j.1467-9280.2007.01992.x.

24 Oyserman, "Self-Concept and Identity."

25 Linda Simon et al., "Terror Management and Cognitive-Experiential Self-Theory: Evidence That Terror Management Occurs in the Experiential System," Journal of Personality and Social Psychology 72, no. 5 (1997): 1132-46, https://doi.org/10.1037/0022-3514.72.5.1132. 
When identities form, no matter where and how, there is a change over one self's life in childhood, adolescence, and adulthood. Oyserman and James ${ }^{26}$ discovered several researchers have explored life transitions and changes to analyze an individual's life stages. Normative movements from one phase to the next are referred to as life transitions. Changes in the availability, dedication, and perceptions about the chances of achieving a particular possible identity are frequently associated with transitions. These changes might happen gradually as new issues emerge over time, or they can happen quickly when new challenges arise due to unanticipated events. Some transitions are best described as the loss of possible identities, while others are better represented as creating possible identities. Transitions to maturity, school transitions, and parenthood transitions are all examples of adding possible identities. Divorce, job loss, and other setbacks are examples of possible identity loss.

\section{B. Method}

This research applied the psychological approach to help the analysis of the novel. The psychological approach to literature argues that psychology (the study or interpretation of the mind and its methods) can be used to assist a literary critic or literary researcher in describing, perceiving, and analyzing

\footnotetext{
${ }^{26}$ Daphna Oyserman and Leah James, "Handbook of Identity Theory and Research," in Handbook of Identity Theory and Research, ed. \& V. L. Vignoles S. J. Schwartz, K. Luyckx (Springer Science + Business Media, 2011), 117-45, https://doi.org/10.1007/978-1-4419-7988-9.
}

literary works. ${ }^{27}$ Psychology can be used to clarify the author's psychology and how it influenced the novel's creation. Furthermore, psychology can be used to describe character development and characterization. Subhan also writes that psychology can explain why a specific character in the novel becomes terrible, good, frustrated, illuminated, or killed by someone. ${ }^{28}$

Based on the statement of Wellek and Warren, ${ }^{29}$ the psychology of literature has four branches as follow:

1. The study of the author's psychology as an individual;

2. The study concerned with the creative process;

3. The study of the types and concepts of psychology applied to literary works;

4. The study of how literary works affect the reader (audience psychology).

By using "psychology of literature" we may observe how the author's passion and emotional experience can influence a work, or how a work's process can be turned into a complete literary work, or how psychological topics and cases are portrayed in the character of literary works, or finally, the impact of literary work on the reader whether it has an impact on the reader's way of thought and life or not. Therefore, it can be inferred that the fourth can be discussed under the heading "Literature and Society", only the

\footnotetext{
27 Bustami Subhan, A Guide to Literary Criticism (Yogyakarta: LPPDMF, 2015), 53.

28 Subhan, 53.

29 Rene Wellek and Austin Warren, Theory of Literature (Harmondsworth: Penguin Books, 1963), 81.
} 
third most likely belongs to literary analysis in the strictest sense, and the first two are sub-disciplines of art psychology. Although they may be served pedagogic approaches to the study of literature at times, we can avoid evaluating literary works in terms of their sources (the genetic fallacy).

\section{Results}

Self-concept and identity come to mind when a person thinks of themselves, including personal and social identities. ${ }^{30}$ By searching self-identity, the doers will find the characteristics which differentiate them in personality, behavior, and social. This lets the researcher finds out that searching for self-identity is an essential part of life. It is as crucial as Kathy and Tommy do as the main characters of the novel Never Let Me Go by Kazuo Ishiguro to find their identity. Narrated by Kathy, she flashed back the memories of how Kathy and Tommy are puzzled because of too many mysteries in Hailsham, the boarding school where they live. They connected each puzzle which could be the answer. But, in the novel, the question they belong to for being different brought them to another question. The process of findings itself flowed as long as they grew.

In this part, after reading and analyzing the novel carefully, the researcher tries to describe the search for self-identity which the main characters in the novel had done. In searching selfidentity, the main characters through life stages in which the researcher used the

${ }^{30}$ Oyserman, "Self-Concept and Identity," 69. theory from Oyserman's identity development. Oyserman and James ${ }^{31}$ considered two primary age and life phase groups: (a) schooling and preparation for adult relationships and jobs, and (b) parenting and career, aging, and the life phase of retirement and health issues. There are processes of finding how self, self-concept, and identity originate by childhood, adolescence, adulthood, and aging. Moreover, Oyserman, Elmore, and Smith ${ }^{32}$ found that self-identity could be stable, mainly occurring in adulthood, if it is confirmed to be the expected.

Oyserman, Elmore, and Smith ${ }^{33}$ also noted that three core notions: self and identities are mental concepts, self and identity are the social product, and self and identity are forces for action. Self, identity, and self-concept all originate from somewhere, which are retained in memory and matter.

\section{Recalling the childhood memories in Hailsham}

Related to Oyserman's theory stated above, Hailsham was the main characters' origin a place where the main characters spent their childhood and grew. It was also a place where they found half of their true selves by the puzzling mysteries there. As stated by Oyserman and James, ${ }^{34}$ children create mental representations of their future ambitions and want in childhood.

\footnotetext{
31 Oyserman and James, "Handbook of Identity Theory and Research." 6-7.

32 Oyserman, Elmore, and Smith, "Self, SelfConcept, and Identity," 75-78.

${ }^{33}$ Oyserman, Elmore, and Smith, 70-74.

34 Oyserman and James, "Handbook of Identity Theory and Research." 124.
} 
Hailsham was a privileged boarding school, somewhere in England, which preferred for human clones. They were familiar with the students. Living about sixteen years in Hailsham, they were raised and taught by several teachers called the guardians.

In Hailsham, there was a guardian called Miss Lucy, who was different. She often gave clues that helped the students, especially Kathy and Tommy, find the answer to the mysteries in Hailsham. Once, Miss Lucy contributed by telling the students about 'told and not told.' It was her opinion that the students did not get any explanation of their existence and the reasons for their whole studies in Hailsham. She told them that they were clones whose futures were to donate their organs to ordinary people. It happened in a year where they were going to graduate from Hailsham. So they were not surprised at all though some puzzles were still questioned.

\section{Kathy related the donation and the rules in Hailsham}

It happened in their last year of childhood stage, about fifteen years old. Kathy narrated as donating is their duty in the future; Hailsham has strict rules, especially related to their health. It proposed that if their time came, they could donate generously. So Kathy related it all to what Miss Lucy said about being 'told and not told' of the donations and the reasons for rules. The whole proofs could be found below:
"Now, to be fair, it was probably natural to run these two subjects together. If, say, they were telling us how we'd have to be very careful to avoid diseases when we had sex, it would have been odd not to mention how much more important this was for us than for normal people outside. And that, of course, would bring us onto the donations." ${ }^{\text {35 }}$

Kathy interpreted that sex and donation had a relation. She thought if the guardians put them in a lesson as was natural. In her opinion, as if the guardians taught them how to avoid the diseases when they had sex, they should tell them why they should be careful of it and its importance, which might be more crucial to them than the ordinary people. So, they would talk about the donation, which they had not told the students, but Miss Lucy had shared.

"Then there was the whole business about our not being able to have babies. Miss Emily used to give a lot of the sex lectures herself, and I remember once, she brought in a lifesize skeleton from the biology class to demonstrate how it was done." ${ }^{36}$

Then the childhood memory of the lesson they had from Miss Emily taught them how not to have babies retold by Kathy. Miss Emily brought a life sizeskeleton from the biology class to show them how they should do it to avoid babies.

"Not just because of the diseases, but because, she said, 'sex affects emotions in ways you'd never expect.'

\footnotetext{
${ }^{35}$ Kazuo Ishiguro, Never Let Me Go (London: Faber and Faber, 2010), 82.

${ }^{36}$ Ishiguro, 82.
} 
We had to be extremely careful about having sex in the outside world, especially with people who weren't students, because, out there, sex meant all sorts of things." ${ }^{37}$

Kathy also told Miss Emily that they should be careful of sex because it affects personal feelings. They should also be cautious if they had sex with ordinary people because sex was meant much more than Hailsham's students in the outer world.

"Miss Emily's lecture that day was typical of what I'm talking about. We'd be focusing on sex, and then the other stuff would creep in. I suppose that was all part of how we came to be 'told and not told." 38

Looking at how Miss Emily lectured them about sex that day was related to what Kathy said. On that day, they focused on sex, and Miss Emily would explain other stuff that referred to the donation they would do in the future. Kathy found out that Miss Lucy said they were 'told and not told' by the guardians. Meanwhile, there was a rule that they were forbidden to smoke. It was related to the donations as proven below:

"It's not good that I smoked. It wasn't good for me, so I stopped it. But what you must understand is that for you, all of you, it's much, much worse to smoke than it ever was for me. "39

According to what Miss Lucy said, even though she had smoked when she was younger, smoke was not good. It was

\footnotetext{
${ }^{37}$ Ishiguro, 82.

${ }^{38}$ Ishiguro, 82.

${ }^{39}$ Ishiguro, 68.
}

much worse for the health of students from Hailsham.

"You've been told about it. You're students. You're... special. So keeping yourselves well, keeping yourselves very healthy inside, that's much more important for each of you than it is for me." ${ }^{\text {40 }}$

The above happened before Miss Lucy told them about 'told and not told' matter. Despite it, smoking was worse than free sex they might have because it could affect their donations in the future. As written, they should keep their health more than anyone else.

"..., some of us were sure she was dying for someone to ask: 'Why? Why is it so much worse for us?' But no one did. I've often thought about that day, and I'm sure now, in the light of what happened later, that we only needed to ask, and Miss Lucy would have told us all kinds of things. All it would have taken was just one more question about smoking." ${ }^{41}$

Kathy retold that they were actually had a question to Miss Lucy, like why it was much worse for the students, but there was ignorance they kept inside rather than asking it to Miss Lucy.

"So why had we stayed silent that day? I suppose it was because even at that age-we were nine or ten-we knew just enough to make us wary of that whole territory. It's hard now to remember just how much we knew by then. We certainly knew-though not in any deep sense-that we were different from our guardians and also from the normal people outside; we perhaps even knew that a long way

\footnotetext{
${ }^{40}$ Ishiguro, 68.

${ }^{41}$ Ishiguro, 68-69.
} 
down the line there were donations waiting for us." 42

The reason was as Kathy represented her old memories in Hailsham, they had known since even they were eight years old that they were different from other ordinary people like the guardians, Madame, the delivers, and people out there. She added they might know the donation awaited them in the future.

On the whole proofs and explanations, it had seen that the search of the main characters to their self-identity in their childhood was helped indirectly by Miss Lucy. They got the clues from her, and she, herself, revealed the reason behind those mysteries in Hailsham. However, Kathy and Tommy were still puzzled by Miss Lucy's last words telling Tommy that being creative was essential and valuable for their future.

Based on Oyserman's theory, it can be said as self and identity are mental constructs. The constructions start from something that is represented in the memory. Children seem to have kept a visual image of who they are. This image is probably quite detailed. ${ }^{43}$ The details were Kathy, Tommy, and Ruth recalled their memories in their childhood as part of finding the clues and consciousness for being different. They could not stop to ask but had no determination to find it out more. The study was obtained on their memory of Madame, who was afraid of them. By that, the old Kathy who narrated

\footnotetext{
42 Ishiguro, 69.

43 Oyserman, Elmore, and Smith, "Self, SelfConcept, and Identity."
}

the story told that they had known for being different from their guardians and ordinary people at that age. Even as kids should be, they still could not interpret the meaning very well.

Kathy also remembered her memory of being 'told and not told' as mentioned by Miss Lucy. No students were surprised. That was related to the importance of sex, and its rules differentiated them from ordinary people. On the other hand, before Miss Lucy revealed the donation, she told them about the worse of smoking for the students. The students understood why they were different from ordinary people, including the guardians.

\section{Findings the "possibles" in Cottage and Norfolk}

As mentioned in Oyserman's identity development theory, searching the selfidentity happens in the students' adolescence. The youngest children either did not give a reason or just described the individual they had selected. But, in early adolescence, they were reasoning substantively centered on the types of civic traits, personal morality, or character adolescents desired to achieve. ${ }^{44}$

When they were sixteen, after the students graduated from Hailsham, Kathy, Tommy, and some students were sent to the Cottages, the remains of a farm in which barns, outhouses, stables surrounded an old farmhouse. All were changed for the students to live in. As time passed, by the unconscious help from the

\footnotetext{
44 Oyserman and James, "Handbook of Identity Theory and Research." 6.
} 
veterans, both three discovered the possible, deferral, and theory Tommy had.

"The basic idea behind the possibles theory was simple and didn't provoke much dispute. It went something like this. Since each of us was copied at some point from a normal person, there must be, for each of us, somewhere out there, a model getting on with his or her life. This meant, at least in theory, you'd be able to find the person you were modeled from. That's why, when you were out there yourself-in the towns, shopping centers, transport cafés-you kept an eye out for "possibles"-the people who might have been the models for you and your friends. Beyond these basics, though, there wasn't much consensus." 45

Kathy's explanation above about the "possible" was there a student, for example, copied from the normal person. So as the theory came along, they believed that they could find their possibles in the street, towns, somewhere in public buildings. Even at first, there was no one believed in it. There was a debate about the age of the possibles; some thought they might be as old as the ordinary parents for clones above 16 years old. But others had different opinions which no matter who was their possibles there left something which made less distinguishable from their condition.

\section{a. Kathy takes a look into porn magazine to find her possible}

Kathy reminisced her past memory of how she found her possible in porn magazines. One day, she passed the boiler hut. Keffers, the old man just left the porn magazines she hated. An idea came by then she took it inside the boiler hut. The strange thing was she focused on their faces instead. The whole proofs of quotation can be seen as written below:

"But when I found myself strolling past the boiler hut about half an hour later, I saw the magazines hadn't been touched. I thought for a moment about taking them up to my room, but then I could see if they were ever found there, l'd get no end of teasing; and how there was no way people would understand my reasons for doing such a thing. That was why I picked up the magazines and went inside the boiler hut with them." ${ }^{46}$

As the above quotation, it explains that Kathy was not planning to take the porn magazines. That day, she was passing the boiler hut and seeing the magazines there. Suddenly she took them inside the boiler hut since it was an excellent place to hide from others; she would not catch up for doing such a shameful thing.

"There were lots of pictures of girls holding their legs open or sticking their bottoms out. I'll admit, there have been times when l've looked at pictures like that and felt excited, though l've never fancied doing it with a girl. But that's not what I was after that afternoon. I moved through the pages quickly, not wanting to be distracted by any buzz of sex coming off those pages. In fact, I hardly saw the contorted bodies because I was focusing on the faces. Even in the little adverts for videos or whatever tucked away to the side, I checked each model's face before moving on." ${ }^{47}$

\footnotetext{
${ }^{46}$ Ishiguro, 132.

47 Ishiguro, 132.
}

${ }^{45}$ Ishiguro, 137.

OKARA: Jurnal Bahasa dan Sastra, Vol. 15, No. 2, November 2021 
Subsequently, Kathy opened each page of the magazines and felt excited, yet she focused on the faces of the naked girls. Even she observed the little adverts on the side of pages carefully before she went on.

"It wasn't until I was nearing the end of the pile that I became certain there was somebody standing outside the barn, just beside the doorway. I'd left the door open because that's how it was normal, and because I wanted the light; and twice already l'd found myself glancing up, thinking l'd heard some small noise. But there'd been no one there, and l'd just gone on with what I was doing. Now I was certain, though, and lowering my magazine I made a heavy sighing sound that would be clearly audible."

Kathy had no consciousness until she was near the end of the magazine if there was somebody who stood beside the doorway. She waited for some slight noise, but there was nothing. So she continued what she was doing.

"So I called out, in what I tried to make a weary tone: 'Delighted you could join me. Why be so shy?' There was a little chuckle, then Tommy appeared at the threshold. 'Hi, Kath,' he said sheepishly." ${ }^{29}$

She called him out in a weary tone. Tommy appeared then under his shyness.

"Then I heard Tommy's steps coming nearer until he was right up to me. When I looked up again, his hands were hovering fretfully in the air, like I was doing a complicated manual task and he was itching to help. 'Kath, you don't... Well, if it's for kicks, you don't do it like that. You've got to look at the pictures much more carefully. It doesn't really work if you go that fast."'How do you know what works for girls? Or maybe you've looked these over with Ruth. Sorry, not thinking.'Kath, what are you looking for.?"50

Tommy came right next to Kathy then helped Kathy. As he said, if she wanted the kicks, she should look at the pictures carefully instead of that fast. But Kathy sounded disturbed, which made Tommy wonder what she was actually looking for.

"I wasn't trying to spy on you. But I did see you, that time last week, after we'd all been up in Charley's room. There was one of these mags there, and you thought we'd all left and gone. But I came back to get my jumper, and Claire's doors were open, so I could see straight through to Charley's room. That's how I saw you in there, going through the magazine.' 'Well, so what? We all have to get our kicks some way. 'You weren't doing it for kicks. I could tell, just like I can now. It's your face, Kath. That time in Charley's room, you had a strange face. Like you were sad, maybe. And a bit scared." ${ }^{.1}$

Tommy explained to Kathy that he saw her last week in Charley's room. He told her that she was there opening the magazine. Even Kathy replied that she did that for seducing herself, but he assumed the opposite. On her face, he said that she was sad and a bit scared.

"I jumped off the workbench, gathered up the mags, and dumped them in his arms. 'Here. Give these to Ruth. See if they do anything for her.' I walked past him and out of the barn. I knew he'd be

\footnotetext{
${ }^{50}$ Ishiguro, 134.

${ }^{51}$ Ishiguro, 134.

48 Ishiguro, 132.

${ }^{49}$ Ishiguro, 133.
}

OKARA: Jurnal Bahasa dan Sastra, Vol. 15, No. 2, November 2021 
disappointed I hadn't told him anything, but at that point, I hadn't thought things through properly myself and wasn't ready to tell anyone. But I hadn't minded him coming into the boiler hut after me. I hadn't minded at all. l'd felt comforted, protected almost. I did tell him eventually, but that wasn't until a few months later when we went on our Norfolk trip." ${ }^{25}$

Kathy seemed to be annoyed at the way she dumped the magazines to Tommy. She admitted she was not ready to tell Tommy the truth of what she did, although Tommy disappointed her. But she did tell Tommy a month later when they had a Norfolk trip.

" 'But I still don't really get it, Kath,' he said eventually. 'Even if what Ruth says is right, and I don't think it is, why are you looking through old porn mags for your possibles? Why would your model have to be one of those girls? 'I shrugged, still not looking at him. 'I don't claim it makes sense'." ${ }^{\text {. }}$

Tommy told Kathy his wander to what Kathy did that day. He thought it was not made sense of how a model in porn magazines could be her possible.

"Okay, there's no sense in it,' I said. 'But we all do it, don't we? We all wonder about our model. After all, that's why we came out here today. We all do it." ${ }^{\prime 4}$

After debating with herself, Kathy admitted that in the end, what she did was correct as Tommy's thought. She looked for her possible in porn magazines even she knew that it was unmade sense. But it did not bother her because a lot of them were looked for their possible in many different ways.

\section{b. Kathy and Tommy join the veterans' trip to Norfolk to see Ruth's possible}

Kathy and Tommy joined the veteran to Norfolk, which in the past, as Hailsham students remembered, they called it a place of lost corner. They went there to find Ruth's possible, as Rodney evidenced last time.

"...I wasn't keen on Ruth going with them to Norfolk, though I couldn't really say why. And once it became clear she was completely set on going, I told her l'd come too. At first, she didn't seem too delighted, and there was even a hint that she wouldn't let Tommy come with her either. In the end, though, we all went, the five of us: Chrissie, Rodney, Ruth, Tommy and me." 55

At first, Kathy did not feel sure about Ruth going with Chrissie and Rodney to Norfolk. In the end, even Ruth seemed forbidding Tommy to come; they all went together with Chrissie and Rodney to Norfolk.

"So by the time, we set off again, following Rodney in search of the office where he'd seen Ruth's possible the month before, the atmosphere between us was worse than ever. Things weren't helped either by Rodney repeatedly taking us down the wrong streets. At least four times, he led us confidently down a turning off the High Street, only for the shops and offices to run out, and we'd have to turn and come back. Before long, Rodney was looking defensive and on the verge of giving up. But then we found it."

\footnotetext{
${ }^{55}$ Ishiguro, 142.

${ }^{56}$ Ishiguro, 156.

52 Ishiguro, 134-135.

53 Ishiguro, 178.

54 Ishiguro, 179.
}

OKARA: Jurnal Bahasa dan Sastra, Vol. 15, No. 2, November 2021 
They followed Rodney to the place, an office, where he saw Ruth's possible. But the situation was getting worse because Rodney repeatedly took them down in the wrong streets. Finally, a fourth, he confidently turned off the High Street. There they found the possible.

"There. Over in that corner. In the blue outfit. Her, talking now to the big red woman.' It wasn't obvious, but the longer we kept looking, the more it seemed he had something. The woman was around fifty and had kept her figure pretty well. Her hair was darker than Ruth's-though it could have been dyed-and she had it tied back in a simple pony-tail the way Ruth usually did. She was laughing at something her friend in the red outfit was saying, and her face, especially when she was finishing her laugh with a shake of her head, had more than a hint of Ruth about it." 57

He pointed over the office corner and told them the possible was the woman who wore a blue outfit. Kathy analyzed the woman who seemed fifty, and her figure was well. She had darker hair than Ruth's, and she had it tied back in a simple ponytail which Ruth usually did. The woman was laughing at something, her friend in a red outfit.

"We all kept on watching her, not saying a word. Then we became aware that in another part of the office, a couple of the other women had noticed us. One raised a hand and gave us an uncertain wave. This broke the spell, and we took to our heels in giggly panic." ${ }^{\text {5 }}$

\footnotetext{
57 Ishiguro, 157.

58 Ishiguro, 157.
}

Based on Kathy's narration, they kept their eyes on the woman. But, they were aware in another part of the office; other couple women had noticed them. One raised a hand and waved uncertainly at them. It made them panic.

"Before long there was only the woman and us in the entire street, and if she'd glanced back, there was no way she wouldn't have noticed us. But she just kept walking, a dozen or so steps ahead, then went in through a doorinto The Portway Studios."

They kept following the woman and kept the distance so she would not notice them. And they went through "The Portway Studios" door as following that woman.

"But now, in that gallery, the woman was too close, much closer than we'd ever really wanted. And the more we heard her and looked at her, the less she seemed like Ruth." 60

Then they realized after seeing the woman closely, the more they heard and looked at her, the less she looked alike with Ruth.

"Then suddenly the woman had left, and we all kept standing about, avoiding each other's eyes. But none of us had thought to follow the woman, and as the seconds kept ticking on, it became like we were agreeing, without speaking, about how we now saw the situation." 61

The above quotation explains that they were no longer wanted to follow the woman who had left the Gallery. They had

\footnotetext{
${ }^{59}$ Ishiguro, 159.

${ }^{60}$ Ishiguro, 161.

${ }^{61}$ Ishiguro, 161.
} 
known whether the woman was Ruth's possible or not.

"Well, I think we're agreed, aren't we? That isn't Ruth.' She gave a small laugh and laid a hand on Ruth's shoulder. 'I'm sorry. We're all sorry. But we can't blame Rodney really. It wasn't that wild a try. You've got to admit, when we saw her through those windows, it did look...' She trailed off, then touched Ruth on the shoulder again." ${ }^{2}$

As in the above quotations, Chrissie was the first who dared to talk with Ruth about what just happened: the woman was not her possible. But, she also would not like Rodney to be blamed for how she spoke to protect him.

"Then Tommy said: 'I don't see what difference it makes. It was just a bit of fun we were having. "A bit of fun for you maybe, Tommy,' Ruth said coldly, still gazing straight ahead of her. 'You wouldn't think so if it was your possible we'd been looking for.'I think I would,' Tommy said. 'I don't see how it matters. Even if you found your possible, the actual model they got you from. Even then, I don't see what difference it makes to anything'."

Tommy assessed that the possible was unnecessary because it did not influence their future life, no matter the kind of model they had. Ruth replied that Tommy stated that because it was not him. They only found a funny thing, which made no difference; he would not take it so seriously if he experienced it.

"...That other woman in there, her friend, the old one in the gallery. Art students, that's what she thought we were. Do you think she'd have talked to us like that if she'd known what we really were? What do you think she'd have said if we'd asked her? 'Excuse me, but do you think your friend was ever a clone model?' She'd have thrown us out. We know it, so we might as well just say it. If you want to look for possibles, if you want to do it properly, then you look in the gutter. You look in rubbish bins. Look down the toilet; that's where you'll find where we all came from." 64

Then Ruth told her thoughts as a boom exploded uncontrollably. She harshly said to Chrissie and Rodney that the 'possible was impossible' using people kind of that woman. Trashes such as junkies, prostitutes, winos, tramps, convicts, and as long as not psychos could be their possible. Ruth's words showed that their self-identity was influenced by the social environment, which referred to where they were from and how others would act if they knew clones near them. It is related to Oyserman's theory that self and identity are social products. Schooling, culture, time and location in which one lives, and early life experiences can all contextual influence the self. Contextual impacts on the self can also be proximate, meaning the psychological implications of the current circumstance ${ }^{65}$. Then she referred to Tommy, who kept talking possible as a fun thing. She sarcastically said that the response would be different if people they met knew that they were clones. It was a miserable thing they could imagine. So

\footnotetext{
64 Ishiguro, 164.

65 Oyserman, Elmore, and Smith, "Self, SelfConcept, and Identity."
} 
Ruth asked them to be logical and told them to look for the possible in an appropriate place of the 'trashes.'

The search for possible, a copy of them was failed. It means that there were no changes to them in finding their real possible. In their adolescent stage, as stated in Oyserman's identity development, they would find their curiosity about the new world they just faced, like the existence of possibles. Role models drew adolescents' attention. ${ }^{66}$

Continuing as Kathy told the story in their adolescence, the failure happened to Kathy and Ruth. Kathy, an unmade sense, tried to find her possible by opening porn magazines in which the girls were totally naked and primarily young. Meanwhile, Ruth was too stupid to follow Rodney and Chrissie by believing their words that Rodney saw her possible in Norfolk because of the similarity with her job dream. Yet they realized the fool stuff they did; Ruth harshly said that they were from trashes. It meant they were not from those good and educated people; their identity was from the social environment of the people from junkies, prostitutes, winos, and tramps. Added, Ruth also thought the woman who talked with them in Gallery might act differently if she knew they were clones.

\section{Trying to get the deferral in Littlehampton.}

The deferral was if a couple of two clones was properly in love and they could prove it to the people who ran Hailsham,

66 Oyserman and James, "Handbook of Identity Theory and Research." 124. those people could postpone their donations for a few years. As stated in Oyserman's identity development, their possible identities are centered on occupational and interpersonal matters such as marriage; that family and parenting possible identities become increasingly essential in the middle adult years, and that job-oriented possible identities become less relevant as persons approach later adulthood. ${ }^{67}$

Kathy and Tommy had a will to have a few years to live together as the ordinary couple before the donations. However, in the end, they found the deferral did not exist. Kathy and Tommy found there was no information from Madame and Miss Emily. It happened after Tommy and Kathy told their motive to see Madame.

"I told her what we'd heard, the rumors about Hailsham students and deferrals; how we realized the rumors might not be accurate, and that we weren't banking on anything. 'And even if it is true,' I said, 'we know you must get tired of it, all these couples coming to you, claiming to be in love. Tommy and me, we never would have come and bothered you if we weren't really sure.' 'Sure?' It was the first time she'd spoken for ages and we both jolted back a bit in surprise."

Kathy, then, told her what they had heard about Hailsham students. By it, she claimed they were sure about it. That was the reason why she and Tommy came to see her and asked for the deferrals. Unfortunately, Madame was a little bit

\footnotetext{
${ }^{67}$ Oyserman and James. 124.

${ }^{68}$ Ishiguro, 247.
} 
surprised by Kathy's 'sure' of being in love.

"You believe this? That you're deeply in love? And therefore you've come to me for this... these deferrals? Why? Why did you come to me?" 66

Madame was asked them sarcastically about their love. She went to ask them why they came to her for deferrals.

"We came to see you because of your gallery. We think we know what your gallery's for.'My gallery?' She leaned back on the window ledge, causing the curtains to sway behind her, and took a slow breath. 'My gallery. You must mean my collection. All those paintings, poems, all those things of yours I gathered over the years. It was hard work for me, but I believed in it, we all did in those days. So you think you know what it was for, why we did it. Well, that would be most interesting to hear. Because I have to say, it's a question I ask myself all the time." ${ }^{69}$

Tommy told her that they looked for her because of her Gallery. He said he knew the use of it. Then Madame said it was her collection. All the works she had gathered over the years in a purpose but she wanted to know the prediction of its use.

"...Now why, young man, explain it to me. Why would my gallery help in telling which of you were really in love? 'Because it would help show you what we were like,' Tommy said. 'Because...' 'Because of course'-Madame cut in suddenly-your art will reveal your inner selves! That's it, isn't it? Because your art will display your souls!"70
Furthermore, Madame asked Tommy about her Gallery, which could help those who were in love. But, when Tommy was going to clearly explain the meaning of the art of what they were like, Madame suddenly cut his words and told him that the arts could display their souls; there were no more means.

'You speak to them,' Madame said, as though washing her hands of everything. But she remained standing behind the wheelchair, her eyes blazing towards us." ${ }^{71}$

Then Madame offered her talk to Miss Emily, but she was still standing behind Miss Emily in wheelchairs.

"Miss Emily said. 'I'm the one to whom you should be speaking. Marie-Claude worked hard for our project...."72

Miss Emily came and took the conversation with Kathy and Tommy with Madame, whose name was Marie-Claude. She told them that she was in charge they should talk with because Madame had been related to the best arts project they knew were taken to Madame's Gallery.

"..., so I said: 'What we want to know now, Miss Emily, is if the rumor's true or not." ${ }^{\text {73 }}$

Afterward, a little bit of talk of politeness, Kathy asked Miss Emily if the deferral was existed or not.

"...But I began to think, well, perhaps I shouldn't worry. It's not my doing, after all. And for the few couples who get disappointed, the rest will never put it

\footnotetext{
${ }^{71}$ Ishiguro, 250.

72 Ishiguro, 251.

${ }^{73}$ Ishiguro, 252.

${ }^{69}$ Ishiguro, 248.

${ }^{70}$ Ishiguro, 248.
}

OKARA: Jurnal Bahasa dan Sastra, Vol. 15, No. 2, November 2021 
to the test anyway. It's something for them to dream about, a little fantasy. What harm is there? But for the two of you, I can see this doesn't apply. You are serious. You've thought carefully. You've hoped carefully. For students like you, I do feel regret. It gives me no pleasure at all to disappoint you. But there it is." ${ }^{74}$

Then, Miss Emily tried to explain to them the story of deferrals. There were times she wanted to stamp it out, but it soon raised and was a rumor. Meanwhile, years passed, while Miss Emily began to think the same as Madame, who believed like let the buzz fool them. So she would not care for the couples who got disappointed because it was not her who spread it out. On the other hand, she found both Tommy and Kathy were serious about getting the deferral. Pity them; there was nothing to do for it caused the deferrals did not exist.

According to Oyserman dan James $^{75}$, the self is a social construct made up of connections and interactions with significant persons. The theory of Oyserman's self and identity are social products can be seen from how Madame and Miss Emily did not support them to get the chance of deferral because it did not exist at all.

"So I asked: 'Is it the case, then, that deferrals don't exist? There's nothing you can do?' She shook her head slowly from side to side. 'There's no truth in the rumor. I'm sorry. I truly am.' Suddenly Tommy asked: 'Was it true once though? Before Hailsham

\footnotetext{
74 Ishiguro, 252-253.

75 Oyserman and James, "Handbook of Identity Theory and Research." 119-120.
}

closed?' Miss Emily went on shaking her head." ${ }^{\prime 6}$

Kathy asked again to confirm; it was that deferrals did not ever exist. She had a little bit of hope, but Miss Emily dropped the last. Tommy was then asked for its existence before Hailsham closed, but there was no hope of it as Miss Emily repeated to shake her head.

In the end, Kathy and Tommy accepted who they were and the identity given to them-as clones. Then Kathy and Tommy moved on with their lives, concluding that they would die when they were finished because that was "what they are made for."

It can be highlighted that although each individual can choose their own identity, the presence of a self-identity has always been a puzzle. An individual sometimes must accept who they are and the identity that has been granted to them because there may be a conflict between an individual's wants and the desires of the social environment.

However, it is still interesting to investigate the search for self-identity since, first, self-identity seems can predict behavior over time. Second, self-identity comes to mind feels real and stable yet. The self-identity is highly malleable and can even be dynamically constructed at the moment, so stability often is more seeming than real. Third, self-identity exists over time. An individual can and do imagine the self-continuing over time and from childhood can imagine some desired and undesired future identities.

${ }^{76}$ Ishiguro, 253. 


\section{Conclusion}

Kazuo Ishiguro's Never Let Me Go depicts the quest for self-identity; one as a clone and one as a human. By deploying Oyserman's theory, it is found that identity is a conscious process from childhood to adulthood. Identity has a dynamic nature that moves and changes depending on the situation or event that each individual experiences. An individual creates mental representations of their future ambitions and wants in childhood. In early adolescence, they were reasoning centered on civic traits, personal morality, or character that adolescents desired to achieve. In the middle adult, identity is centered on occupational and interpersonal matters such as marriage. Self-identity could be stable, mainly occurring in adulthood.

This research revealed that selfidentity could be shaped by mental construct, social products, and force for action. The constructions of self-identity start from something that is represented in the memory. Schooling, culture, time and location in which one lives, and early life experiences can also influence selfidentity shaping. The last is that actions matters to self-identity. However, in reality, the existence of a self-identity has remained a mystery. Sometimes, an individual should accept who they are and the identity given to them. It is because, there might be a gap between an individual's desire and the social environment's desire.

\section{References}

American Library Association. "2006 Alex Awards," 2007. http://www.ala.org/yalsa/booklistsaw ards/bookawards/alexawards/alex06.

Carver, Charles S., and Michael F. Scheier. "Self-Focusing Effects of Dispositional Self-Consciousness, Mirror Presence, and Audience Presence." Journal of Personality and Social Psychology 36, no. 3 (1978): 324-32. https://doi.org/10.1037/00223514.36.3.324.

Chatterjee, Arnab. "Exploring an AntiUtopian Subtext in Kazuo Ishiguro's Never Let Me Go." Interdisciplinary Literary Studies 21, no. 2 (2019): 109-24.

https://doi.org/10.5325/intelitestud.2 1.2.0109.

Gardner, Wendi L., Shira Gabriel, and Angela Y. Lee. 'I' Value Freedom, but 'We' Value Relationships: SelfConstrual Priming Mirrors Cultural Differences in Judgment." Psychological Science 10 , no. 4 (1999): 321-26. https://doi.org/10.1111/14679280.00162 .

Horowitz, Mardi. J. "Self-Identity Theory and Research Methods." Journal of Research Practice 8, no. 2 (2012): $1-11$.

Ishiguro, Kazuo. Never Let Me Go. London: Faber and Faber, 2010.

Kettle, Keri L., and Gerald Häubl. "The Signature Effect: Signing Influences Consumption-Related Behavior by Priming Self-Identity." Journal of Consumer Research 38, no. 3 (2011): 474-89. https://doi.org/10.1086/659753.

Lewis, Michael and Jeanne Brooks-Gunn. Social Cognition and the Acquisition of Self. New York: Plenum, 1979. https://doi.org/10.1007/978-1-46843566-5. 
Matthews, Sean, and Sebastian Groes. Kazuo Ishiguro: Contemporary Critical Perspectives. London: Continuum International Pub. Group, 2010.

Miller, Laura. Literary Wonderlands: $A$ Journey through the Greatest Fictional Worlds Ever Created. London: Modern Books, 2017.

Nielsen, Mark, Thomas Suddendorf, and Virginia Slaughter. "Mirror SelfRecognition beyond the Face." Child Development 77, no. 1 (2006): 17685. https://doi.org/10.1111/j.14678624.2006.00863.x.

Oyserman, Daphna. "Self-Concept and Identity." In Intraindividual Processes, edited by Abraham Tesser and Norbert Schwarz, 499517. Malden, MA: Blackwell Publishers, 2001.

Oyserman, Daphna, Kristen Elmore, and George Smith. "Self, Self-Concept, and Identity." In Handbook of Self and Identity, edited by Mark R. Leary and June Price, 69-104. New York: Guilford Press, 2012

Oyserman, Daphna, and Leah James. "Handbook of Identity Theory and Research." In Handbook of Identity Theory and Research, edited by \& V. L. Vignoles S. J. Schwartz, K. Luyckx, 117-45. Springer Science + Business Media, 2011. https://doi.org/10.1007/978-1-44197988-9.

Simon, Linda, Jeff Greenberg, Eddie Harmon-Jones, Tom Pyszczynski, Sheldon Solomon, Jamie Arndt, and Teresa Abend. "Terror Management and Cognitive-Experiential SelfTheory: Evidence That Terror Management Occurs in the Experiential System." Journal of Personality and Social Psychology 72, no. 5 (1997): 1132-46. https://doi.org/10.1037/0022-

3514.72.5.1132.
Skripka, Taufik Wahyu. "Kathy H's Struggle For Getting True Love In Kazuo Ishiguro's Never Let Me Go Novel (2005): An Individual Psychological Approach." Universitas Muhammadiyah Surakarta, 2014.

Subhan, Bustami. A Guide to Literary Criticism. Yogyakarta: LPPDMF, 2015.

Sui, Jie, and Shihui Han. "Self-Construal Priming Modulates Neural Substrates of Self-Awareness." Psychological Science 18, no. 10 (2007): 861-66. https://doi.org/10.1111/j.14679280.2007.01992.x.

"The Nobel Prize in Literature 2017," 2017.

https://www.nobelprize.org/prizes/lit erature/2017/summary/.

Trafimow, David, Harry C. Triandis, and Sharon G. Goto. "Some Tests of the Distinction Between the Private Self and the Collective Self." Journal of Personality and Social Psychology 60, no. 5 (1991): 649-55. https://doi.org/10.1037/00223514.60.5.649.

Vichiensing, Matava. "The Othering in Kazuo Ishiguro's Never Let Me Go." Advances in Language and Literary Studies 8, no. 4 (2017): 126-35. https://doi.org/10.7575/aiac.alls.v.8n .4p.126.

Wellek, Rene, and Austin Warren. Theory of Literature. Harmondsworth: Penguin Books, 1963.

Yeung, Virginia. "Mortality and Memory in Kazuo Ishiguro's Never Let Me Go." Transnational Literature 9, no. 2 (2017): $1-13$. https://doaj.org/article/d583068eff42 4a06853bde278f5c4bcc. 